\title{
In vivo effects of propranolol on some cellular and humoral immune functions in a group of patients with lepromatous leprosy
}

\author{
R ANDERSON,* EMS GATNER, ${ }^{\dagger}$ FMJH IMKAMP $\ddagger \&$ \\ S H KOK $\ddagger$ \\ *The Immunology Section, Department of Medical Microbiology, \\ Institute of Pathology, University of Pretoria: ${ }^{\dagger} M R C$ Tuberculosis \\ Research Institute, Pretoria, and $\$$ West fort Leprosarium, Pretoria, \\ $R S A$
}

Received for publication 20 October 1979

\begin{abstract}
Summary Certain functions of blood neutrophils and lymphocytes were investigated at varying time intervals after the addition of propranolol to standard therapy in a group of patients with lepromatous leprosy. A control group of patients received standard therapy only. The leucocyte functions tested were neutrophil chemotaxis, phagocytosis and NBT reduction and lymphocyte mitogen induced transformation, leucocyte inhibitory factor production and number of spontaneous E, E and EAC rosettes. Serum immunoglobulins, complement components and total haemolytic complement were also measured in both groups. Over a 3-month period neutrophil chemotaxis, numbers of active-E and $E$ rosettes, lymphocyte transformation and lymphokine production improved on standard therapy alone. However, although the propranolol group had the highest mean responses, there were no significant differences between the two groups of patients after one month and three months. Likewise there was no difference between the two groups with respect to other cellular or humoral investigations. Neutrophil chemotaxis appeared to be the best functional correlate of clinical improvement.
\end{abstract}

\section{Introduction}

Cell-mediated immune responses such as lymphocyte transformation to mitogens and antigens (Bullock and Fasal, 1971; Rea and Levan, 1977; ${ }^{2}$ Nath et al, 1977), ${ }^{3}$ lymphokine production (Godal, 1972;4 Talwar, 1972; $;^{6}$ Myrvang, $1973)^{6}$ and numbers of circulating T (Dwyer et al., 1974; $;^{7}$ Sher et al., 1976) ${ }^{8}$ and B (Mendes et al., 1974; ${ }^{9}$ Sher et al., 1976) ${ }^{8}$ lymphocytes are depressed in RSA.

Correspondence: Dr R Anderson, Institute of Pathology, PO Box 2034, Pretoria 0001, 
patients with lepromatous leprosy. Likewise phagocytic cell functions such as neutrophil motility (Bullock et al., 1974;10 Ward et al., 1976;11 Sher et al., 1978) ${ }^{12}$ and macrophage ingestion of Mycobacterium leprae (Barbieri and Correa, 1967:13 Convit et al., 1974) ${ }^{14}$ have been reported to be abnormal in these patients.

Recently propranolol has been shown to possess immunostimulatory activity. This drug has been reported to increase normal and abnormal neutrophil motility in vitro (Anderson and Van Rensburg, 1978;15 Anderson and Van Rensburg, 1979). ${ }^{16}$ Buckley and McGregor (1978) ${ }^{17}$ have reported that propranolol increased the number of survivors, decreased the duration of disease and increased the number of peritoneal exudate cells in rats which had been experimentally infected with type III pneumococci by increasing granulocyte adhesion. Furthermore propranolol can cause increased antibody synthesis in mice (Nakazawa et al., 1976) ${ }^{18}$ and rats (Benner et al., 1968). ${ }^{19}$

We have previously reported (Anderson and Van Rensburg, 1979) ${ }^{16}$ that the profile of effects of propranolol on leucocyte function in vitro is similar to that of levamisole. However the concentration of propranolol required to achieve stimulation of leucocyte function in vitro is approximately ten-fold less (Anderson and Van Rensburg, 1979). ${ }^{16}$ For this reason a pilot study was undertaken to assess the immunologic status of a group of patients with lepromatous leprosy, also receiving standard therapy, before and after the administration of propranolol. No attempt was made to carry out a formalized clinical trial but changes in the clinical and histopathological picture were compared to the laboratory findings.

\section{Patients}

Twelve new untreated admissions (six borderline (BL), two sub-polar (LI) and four lepromatous (LL) were paired according to type of leprosy, age and sex (six males and six females). The classification was based on clinical and histopathological criteria of Ridley and Jopling (1966). All patients showed negative skin tests to lepromin. Patients in the control group received standard therapy of rifampicin ( $600 \mathrm{mg}$ daily) for 6 weeks and dapsone (DDS, $100 \mathrm{mg}$ daily) thereafter. The effects of treatment on immune functions were assessed by comparision of pre-treatment results with those obtained during treatment. Thus each patient served as his own control.

\section{Propranolol}

Each patient in the experimental group in addition to standard therapy received the beta-adrenoreceptor blockading agent propranolol in a fixed dose 
of $40 \mathrm{mg}$ t.i.d. over a twelve-week period. Clinical evaluation and immunological testing were done at the outset and during (one and three months) propranolol therapy. Histopathology on biopsy specimens was performed at the outset and after 3 months. They were assessed for cellular composition, bacterial index (BI) and the granularity index (GI) of the bacteria.

\section{Cellular studies}

\section{NEUTROPHIL MOTILITY}

Neutrophils were obtained from heparinized venous blood (5 units heparin/ml), washed twice with Hank's balanced salt solution (HBSS, Grand Island Biological Company, NY, USA) supplemented with $1 \mathrm{~g} / 1$ of Hepes (Sigma, St Louis, Missouri, USA) to give a final $\mathrm{pH}$ of 7.2 and resuspended to a final concentration of $5 \times 10^{6} / \mathrm{ml}$. Two leucoattractants were used in the study:

(a) Fresh pooled normal sera activated with $100 \mu \mathrm{g} / \mathrm{ml}$ of bacterial endotoxin (E. coli: 0127: B8 Difco, Detroit, Mich, USA).

(b) Endotoxin activated autologous serum. Both types of EAS were incubated for $30 \mathrm{~min}$ at $37^{\circ} \mathrm{C}$ followed by an eight-fold dilution with HBSS. Neutrophil motility was assessed as previously described (Anderson and Van Rensburg, 1979). ${ }^{16}$ Chambers were incubated and the results expressed as the average number of cells reaching the lower surface of the $5 \mu$ pore size Millipore after 3 hours incubation and expressed as an average for triplicate filters.

\section{PHAGOCYTOSIS}

This was assessed as previously described, by the ingestion of Candida albicans (Anderson and Van Rensburg, 1979). ${ }^{16}$ Results are expressed as percentage $C$. albicans ingested in the presence of $10 \%$ fresh autologous serum.

\section{NITRO BLUE TETRAZOLIUM REDUCTION}

Tests of resting and stimulated (semi-quantitative) NBT reduction were performed according to the method of Sher et al. (1974). ${ }^{21}$ The percentage of NBT (reduced) containing PMN was evaluated. For the resting test the normal result is $<10 \%$ positive PMN and in the stimulated test $>90 \%$.

\section{LYMPHOCYTE TRANSFORMATION}

Blood for studies of lymphocyte function was defibrinated and fractionated by density gradient centrifugation (Ficoll-sodium metrizoate) at $400 \mathrm{~g}$ for $25 \mathrm{~min}$. 
Mononuclear cells were washed twice in RPMI (Grand Island Biological Co, NY, USA). $2 \times 10^{5}$ cells $(50 \mu l)$ were used in the assay which was done as previously described using PHA and CON A as the mitogens at concentrations of 25 and $50 \mu \mathrm{g} / \mathrm{ml}$ (Anderson et al., 1979). ${ }^{22}$

\section{LEUCOCYTE MIGRATION INHIBITION FACTOR (LIF) PRODUCTION}

To $17 \times 100 \mathrm{~mm}$ polypropylene culture tubes was added $0.5 \mathrm{ml}$ mononuclear cell suspension $\left(4 \times 10^{6} / \mathrm{ml}\right), 0.1 \mathrm{ml} \mathrm{TC} 199$ or $0.1 \mathrm{ml} \mathrm{PHA}(25 \mu \mathrm{g}$ and $50 \mu \mathrm{g} / \mathrm{ml})$ and the volume adjusted to $1 \mathrm{ml}$ by the addition of serum supplemented TC199. The tubes were incubated at $37^{\circ} \mathrm{C} / 96 \mathrm{hrs}$ in a humidified atmosphere of $3 \% \mathrm{CO}_{2}$ in air. The cell free supernatant was removed and assayed for LIF according to the method of Weisbart and Mickey (1977). ${ }^{23}$ Using human blood neutrophils as the indicator cells. Migration zones in the presence and absence of LIF containing supernatants were measured microscopically using a $\times 2.5$ objective and a calibrated eyepiece graticule. The results are expressed as percentage inhibition of migration as calculated by comparison with the control system.

\section{E AND EAC ROSETTES}

Rosetting techniques were performed according to the method of Brain and Marston (1973). ${ }^{24}$ Briefly, lymphocytes obtained by density gradient centrifugation were further purified by the elimination of contaminating phagocytic cells by iron adherence. The ratio of lymphocytes to E and EAC was 1:10. For EAC rosettes pooled human $A B$ serum was used as a sub-lytic source of complement. Active E-rosettes were measured according to the method of Wybran and Fudenberg (1973). ${ }^{25}$ The lymphocyte : sheep red blood cell ratio was $1: 10$. The mixture was centrifuged at $250 \mathrm{~g} / 5 \mathrm{~min}$ before immediate counting of rosettes. A lymphocyte which had bound 3 or more red cells constituted a rosette.

\section{Serological investigations}

\section{IMMUNOGLOBULINS AND COMPLEMENT COMPONENTS}

The serum levels of IgG, IgA and IgM were determined by radial immunodiffusion using commercial plates and standards (Behring Institute). Serum C-3 and C-4 complement levels were assayed by rocket immunoelectrophoresis (Axelsen, Kroll, Weeke, 1973;26 Laurell, 1972) ${ }^{27}$ Results of immunoglobulin and complement estimations are expressed as $\mathrm{mg} / 100 \mathrm{ml}$ and $\mathrm{mg} / 1000 \mathrm{ml}$ respectively. Serum IgE levels were measured by radioimmunoassay (Phadebas 
IgE test, Pharmacia diagnostics) and results expressed as $\mathrm{IU} / \mathrm{ml}$. The upper limit of normal is taken as $150 \mathrm{IU} / \mathrm{ml}$. Serum CRP levels were measured by a semiquantitative latex agglutination procedure, the normal value being $<13.2 \mu \mathrm{g} / \mathrm{ml}$. ASO antibodies were measured by inhibition of lysis of sheep red blood cells by streptolysin-O, and results expressed as the reciprocal of the titre (normal value 200).

\section{Results}

\section{CALCULATION AND EXPRESSION OF RESULTS}

Results are expressed as the mean value with standard error of the control and experimental groups for each investigation at each time interval tested. The results of each immunological test for control and experimental groups were compared by the Student's t test.

\section{Neutrophil function}

Results are shown in Table 1. Neutrophil chemotaxis was markedly impaired prior to the commencement of therapy and steadily increased throughout the three-month period, being most noticeable after the inclusion of dapsone. Although the increase in chemotactic responsiveness at one month and 3 months was greatest in the group receiving propranolol, the increase was not significant. The restoration of chemotatic responsiveness appeared to correlate with clinical improvement. Two patients in the control group and one in the experimental group showed no increase in chemotaxis throughout the trial period. These three also had less obvious clinical response to therapy. There was a slight but insignificant impairment of phagocytosis of $C$. albicans which normalized to a similar extent in both groups following therapy. Resting and stimulated NBT reduction was normal in both groups and remained unaffected with therapy.

\section{Lymphocyte function}

Results are shown in Table 2. Three patients in the control group and 3 in the experimental group showed reduced responsiveness to PHA (results $<30,000 \mathrm{cpm}$ ) and CON A (results $<8,000 \mathrm{cpm}$ ). The mean responsiveness to the mitogens increased to a similar extent in both groups following therapy, indicating that the improvement was due to standard therapy alone. A similar improvement in mitogen induced production of LIF, independent of propranolol supplementation, was also observed. Numbers of active-E, E and EAC rosettes were normal prior to therapy (with the exception of 2 with reduced 
Table 1. Neutrophil chemotaxis to EAS, phagocytosis and nitro-blue tetrazolium reduction in a control group of patients with lepromatous leprosy and an experimental group who received propranolol in addition to standard therapy

\begin{tabular}{|c|c|c|c|c|c|c|}
\hline \multirow[t]{2}{*}{ Investigations } & \multicolumn{3}{|c|}{ Control Group* } & \multicolumn{3}{|c|}{ Experimental group $^{\dagger}$} \\
\hline & $\begin{array}{c}\text { Pre- } \\
\text { treatment }\end{array}$ & $\begin{array}{l}\text { 1-month post- } \\
\text { treatment }\end{array}$ & $\begin{array}{l}3 \text { months post- } \\
\text { treatment }\end{array}$ & $\begin{array}{c}\text { Pre- } \\
\text { treatment }\end{array}$ & $\begin{array}{l}1 \text { month Post- } \\
\text { treatment }\end{array}$ & $\begin{array}{l}3 \text { months post- } \\
\text { treatment }\end{array}$ \\
\hline $\begin{array}{l}\text { Chemotaxis to: } \\
\text { a. Normal EAS (cells/HPF) } \\
\text { (Normal value }>180 \text { cells/HPF) } \\
\text { b. Autologous EAS }(\text { Cells/HPF) } \\
\text { (Normal value }>180 \text { cells/HPF) }\end{array}$ & $\begin{array}{l}56 \pm 19.7 \S \\
26 \pm 8.1\end{array}$ & $\begin{array}{l}95 \pm 45.0 \\
52 \pm 31.0\end{array}$ & $131 \pm 36.0$ & $\begin{array}{l}67 \pm 25.5 \\
46 \pm 15.2\end{array}$ & $73.1 \pm 19.3$ & $\begin{array}{l}232 \pm 27.7 \\
191 \pm 26.8\end{array}$ \\
\hline $\begin{array}{l}\text { Phagocytosis of } C \text {. albicans } \\
\text { (\% ingestion } / 25 \mathrm{~min}) \\
(\text { Normal value }>90 \%)\end{array}$ & $80 \pm 6.4$ & $82 \pm 3.9$ & $94 \pm 1.6$ & $86 \pm 1.6$ & $86 \pm 2.7$ & $95 \pm 0.7$ \\
\hline $\begin{array}{l}\text { NBT Reduction } \\
\text { a. Resting } \\
\text { (Normal value }<10 \%) \\
\text { b. Stimulated } \\
\text { (Normal value }>90 \%)\end{array}$ & $\begin{array}{l}10 \pm 4.6 \\
97 \pm 0.9\end{array}$ & $\begin{array}{l}4.6 \pm 1.9 \\
92 \pm 1.1\end{array}$ & $\begin{array}{l}8.7 \pm 2.6 \\
95 \pm 1.1\end{array}$ & $\begin{array}{l}11 \pm 3.0 \\
92 \pm 0.5\end{array}$ & $\begin{array}{c}8.7 \pm 3.0 \\
95 \pm 1.3\end{array}$ & $\begin{array}{r}10.3 \pm 3.8 \\
95 \pm 1.1\end{array}$ \\
\hline
\end{tabular}

${ }^{*}$ Receiving standard therapy only.

$\dagger$ Receiving standard therapy and propranolol $40 \mathrm{mg}$ t.d.s.

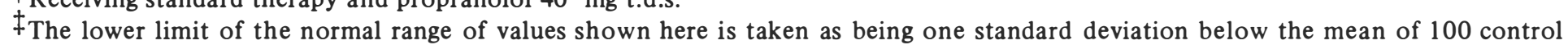
subjects.

$\S$ Results expressed as mean and standard error for six individuals. 
Table 2. Lymphocyte mitogen induced transformation and relative percentages of active E, E and EAC rosetting cells in a control group of patients with lepromatous leprosy and an experimental group who received propranolol in addition to standard therapy

\begin{tabular}{|c|c|c|c|c|c|c|}
\hline \multirow[t]{2}{*}{ Investigation } & \multicolumn{3}{|c|}{ Control Group* } & \multicolumn{3}{|c|}{ Experimental group ${ }^{\dagger}$} \\
\hline & Pre-treatment & $\begin{array}{l}1 \text { month post- } \\
\text { treatment }\end{array}$ & $\begin{array}{l}3 \text { months post- } \\
\text { treatment }\end{array}$ & Pre-treatment & $\begin{array}{l}1 \text { month post- } \\
\text { treatment }\end{array}$ & $\begin{array}{l}3 \text { months post- } \\
\text { treatment }\end{array}$ \\
\hline \multicolumn{7}{|c|}{ Lymphocyte transformation to: } \\
\hline a. $25 \mu \mathrm{g} / \mathrm{ml}$ PHA (cpm) & $26.264 \pm 8.645 \ddagger$ & $47.698 \pm 19.483$ & $45.482 \pm 17.338$ & $25.584 \pm 5.746$ & $59.904 \pm 16.710$ & $58.821 \pm 20.980$ \\
\hline b. $50 \mu \mathrm{g} / \mathrm{ml}$ PHA $(\mathrm{cpm})$ & $30.405 \pm 8.323$ & $45.216 \pm 16.095$ & $43.798 \pm 15.125$ & $23.386 \pm 5.028$ & $48.005 \pm 11.592$ & $50.994 \pm 21.466$ \\
\hline c. $25 \mu \mathrm{g} / \mathrm{ml}$ CON A $(\mathrm{cpm})$ & $7.639 \pm 2.781$ & $12.340 \pm 8.042$ & $18.462 \pm 8.893$ & $1.941 \pm 612$ & $12.255 \pm 3.735$ & $9.35 \pm 2.010$ \\
\hline d. $50 \mu \mathrm{g} / \mathrm{ml} \mathrm{CON} \mathrm{A} \mathrm{(cpm)}$ & $8.205 \pm 4.494$ & $14.934 \pm 7.814$ & $15.702 \pm 7.979$ & $4.199 \pm 1.503$ & $15.862 \pm 5.230$ & $12.156 \pm 2.683$ \\
\hline \multicolumn{7}{|l|}{ Rosetting cells } \\
\hline a. Active E-rosettes (\%) & $47 \pm 8.6$ & $57 \pm 3.0$ & $54 \pm 8.3$ & $38 \pm 10.0$ & $46 \pm 4.0$ & $67 \pm 8.1$ \\
\hline b. E-rosettes (\%) & $62 \pm 5.0$ & $57 \pm 4.5$ & $66 \pm 2.8$ & $57 \pm 7.1$ & $60 \pm 7.1$ & $70 \pm 4.1$ \\
\hline c. EAC-rosettes (\%) & $34 \pm 8.0$ & $25 \pm 8.0$ & $28 \pm 4.3$ & $27 \pm 6.5$ & $27 \pm 4.4$ & $19 \pm 3.5$ \\
\hline
\end{tabular}

c. EAC-rosettes (\%)

$34 \pm 8.0$

$57 \pm 4.5$
$25 \pm 8.0$

$28 \pm 4.3$

$27 \pm 6.5$

${ }^{*}$ Receiving standard therapy only.

$\dagger$ Receiving standard therapy and propranolol $40 \mathrm{mg}$ t.d.s.

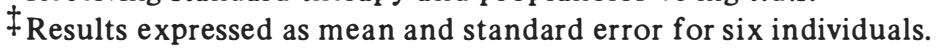


Table 3. Serum immunoglobulin and complement levels in a control group of patients with lepromatous leprosy and an experimental group who received propranolol in addition to standard therapy for a three-month period

\begin{tabular}{|c|c|c|c|c|c|c|}
\hline \multirow[t]{2}{*}{ Investigation } & \multicolumn{3}{|c|}{ Control group* } & \multicolumn{3}{|c|}{ Experimental group ${ }^{\dagger}$} \\
\hline & $\begin{array}{c}\text { Pre- } \\
\text { treatment }\end{array}$ & $\begin{array}{l}1 \text { month post- } \\
\text { treatment }\end{array}$ & $\begin{array}{l}3 \text { months post- } \\
\text { treatment }\end{array}$ & $\begin{array}{c}\text { Pre- } \\
\text { treatment }\end{array}$ & $\begin{array}{l}1 \text { month post- } \\
\text { treatment }\end{array}$ & $\begin{array}{l}3 \text { months post- } \\
\text { treatment }\end{array}$ \\
\hline Serum IgG $(g / l)$ & $33.3 \pm 3.3 \ddagger$ & $33.3 \pm 3.8$ & $29.8 \pm 4.0$ & $33.8 \pm 4.3$ & $37.8 \pm 4.3$ & $31.3 \pm 3.7$ \\
\hline Serum IgA $(g / l)$ & $5.1 \pm 1.1$ & $5.6 \pm 1.2$ & $5.4 \pm 1.1$ & $5.4 \pm 1.0$ & $6.2 \pm 1.0$ & $5.9 \pm 1.1$ \\
\hline Serum IgM $(g / l)$ & $5.0 \pm 1.1$ & $4.3 \pm 0.8$ & $3.8 \pm 0.6$ & $5.0 \pm 1.0$ & $6.4 \pm 1.4$ & $4.1 \pm 0.8$ \\
\hline Serum IgE $(\mathrm{IU} / \mathrm{ml})$ & $595 \pm 248$ & $485 \pm 222$ & $422 \pm 780$ & $1,700 \pm 780$ & $778 \pm 276$ & $1,350 \pm 546$ \\
\hline THC (CH50) & $158 \pm 8.1$ & $162 \pm 9.9$ & $147 \pm 6.6$ & $166 \pm 15.0$ & $170 \pm 20.0$ & $145 \pm 9.2$ \\
\hline $\mathrm{C}^{\prime} 3 \quad(\mathrm{mg} / \mathrm{dl})$ & $71 \pm 7.1$ & $66 \pm 4.5$ & $69 \pm 7.0$ & $65 \pm 3.8$ & $75 \pm 8.4$ & $66 \pm 8.7$ \\
\hline $\mathrm{C}^{\prime} 4 \quad(\mathrm{mg} / \mathrm{dl})$ & $31 \pm 4.9$ & $36 \pm 4.0$ & $25 \pm 3.0$ & $25.3 \pm 6.1$ & $25.5 \pm 4.4$ & $28.6 \pm 7.2$ \\
\hline
\end{tabular}

* Receiving standard therapy only

$\dagger$ Receiving standard therapy and propranolol $40 \mathrm{mg}$ t.d.s.

$\ddagger$ Results expressed as mean and standard error for six individuals 
numbers of EAC rosettes and with reduced numbers of E-rosettes in the control group) and remained unaltered throughout in both groups.

\section{Serological studies}

Serum immunoglobulins, including IgE, were elevated in both groups and remained increased to a similar extent throughout the 3-month period. Likewise levels of $\mathrm{C} 3$ and $\mathrm{C} 4$ and total haemolytic complement were normal at the outset and remained unaffected.

\section{Histological results}

There were no detectable differences between the control and experimental groups with regard to cellular composition of the biopsies, bacterial index and granularity index after 3 months of therapy.

\section{Skin testing}

All patients in each group remained anergic to lepromin after 3 months of therapy.

\section{Patients}

Using clinical criteria there appeared to be no differences between the two groups, although clinical improvement appeared to correlate with the extent of recovery of neutrophil chemotactic responsiveness. There were no adverse reactions to propranolol in the experimental group. The incidence of ENL was the same in both groups $(2 / 6$ in the control and $2 / 6$ in the experimental groups).

\section{Discussion}

This study has confirmed previous reports that some patients with lepromatous leprosy have reduced lymphocyte transformation (Bullock and Fasal, 1971; Rea and Levan, 1977; $;^{2}$ Nath et al., 1977) ${ }^{3}$ and LIF production (Godal, 1972;4 Talwar, 1972; $;^{5}$ Myrvang, 1973) ${ }^{6}$ to mitogens and depressed neutrophil migratory responses to leucoattractants (Bullock et al., 1974; ${ }^{10}$ Ward et al., 1976; ${ }^{11}$ Sher et al., 1978). ${ }^{12}$ However these functions of circulating leucocytes improved, and in almost all cases normalized, following 3 months of standard therapy with rifampicin and dapsone. The inclusion of propranolol, which has been reported to possess immunostimulatory properties, with standard therapy caused further improvement of neutrophil chemotactic responsiveness and 
lymphocyte functions. However the magnitudes of the increases were not significant and did not correlate with any clinical, histopathological or bacteriological differences between the two groups. Likewise skin test unresponsiveness to lepromin was still evident in all members of both groups after the 3-month period.

These results indicate that immunostimulation with presently available agents may be of limited value in patients with lepromatous leprosy. In agreement with this contention is a recent report by Faber et al. (1979) ${ }^{28}$ who were unable to detect any signifcant improvement in in vitro and in vivo immunological functions in a group of patients receiving transfer factor.

Of interest is the recovery of normal blood leucocyte function with standard therapy alone. Increased leucocyte responsiveness in vitro was most evident when dapsone was introduced to the therapeutic regime. Apart from its bacteriostatic effect (McCullough and Maren, 1973), ${ }^{29}$ which may be directly related to improved leucocyte function by lessening the antigenic load and removing the source of serum inhibitors of leucotaxis (Sher et al., 1978) ${ }^{12}$ dapsone may have other modes of action (McDougall, 1979). ${ }^{30}$ One possibility currently being investigated in this laboratory, is that dapsone per se possesses immunostimulatory activity, which may invalidate studies assessing the value of immunostimulants in patients with lepromatous leprosy.

Recovery of neutrophil chemotactic responsiveness appeared to correlate with clinical improvement since the three patients who did not recover normal neutrophil locomotion had the least clinical improvement. This apparent correlation between recovery of chemotaxis and clinical response to therapy is pesently being further investigated.

Although no striking immunological or clinical benefits were observed by the addition of propranolol to standard therapy in patients with lepromatous leprosy it is possible that the duration of the trial period was insufficient. However after 3 months of standard therapy \pm propranolol blood neutrophil and lymphocyte functions had normalized in most patients, which indicates the likelihood that at this stage non-specific immunostimulation may be of little value.

\section{Acknowledgement}

The authors thank Professor IW Simson of the Department of Histopathology, Institute of Pathology, University of Pretoria, for interpretation of the biopsies.

\section{References}

1 Bullock WE, Fasal P. Studies of immune mechanisms in leprosy. J Immunol, 1971, 106, 888. 
2 Rea TH, Levan NE. Current concepts in the immunology of leprosy. Arch Dermatol, $1977,113,345$.

${ }^{3}$ Nath I, Curtis J, Shama AK, Talwar GP. Circulating T-cell numbers and their mitogenic potential in leprosy - correlation with mycobacterial load. Clin Exp Immunol, 1977, 29, 393.

${ }^{4}$ Godal T, Myrvang B, Froland SS, Shao J, Melaku G. Evidence that the mechanism of immunological tolerance (central failure) is operative in the lack of host resistance in lepromatous leprosy. Scand J Immunol, 1972, 1, 311.

5 Talwar GP, Kirishnam AD, Mehra VL, Blum EA, and Pearson JMH. Evaluation of cellmediated immune responses in untreated cases of leprosy. Clin Exp Immunol, 1972, $12,195$.

${ }^{6}$ Myrvang B, Godal T, Ridley DS, Froland SS, Song YK. Immune responsiveness to Mycobacterium leprae and other mycobacterial antigens throughout the clinical and histopathological spectrum of leprosy. Clin Exp Immunol, 1973, 14, 541.

7 Dwyer JM, Bullock WE, Fields, JP. Disturbance of the blood T:B lymphocyte ratio in lepromatous leprosy. New Engl J Med, 1973, 288, 1036.

${ }^{8}$ Sher R, Holm G, Kok SH, Koornhof HJ, Glover A. T and $\mathrm{CR}^{+}$lymphocyte profile in leprosy and the effect of treatment. Infec Immunity, 1976, 13, 31

9 Mendes NF, Kopersztych, S and Mota, NGS. T and B lymphocytes in patients with lepromatous leprosy. Clin Exp Immunol, 1974, 16, 23.

10 Bullock WE, Ho MF, Chen MJ. Quantitative and qualitative studies of the local cellular exudative response in Leprosy. J Reticuloendothel Soc, 1974, 16, 259.

11 Ward PA, Goralnick S, Bullock WE. Defective leukotaxis in patients with lepromatous leprosy. J Lab Clin Med, 1976, 87, 1025.

12 Sher R, Anderson R, Glover A, Wadee AA. Polymorphonuclear cell function in the various polar types of leprosy and erythema nodosum leprosum. Infec Immunity, 1978, $21,959$.

13 Barbieri TA, Correa WM. Human Macrophage Culture: The Leprosy Prognostic Test (LPT). Int J Leprosy 1969, 35, 377.

14 Convit J, Pinardi ME, Rodriguez Ochoa G, Ulrich M, Avila JL, Gothman M. Elimination of Mycobacterium leprae subsequent to local in vivo activation of macrophages in lepromatous leprosy by other mycobacteria. Clin Exp Immunol, 1974, 17, 261.

15 Anderson R, Van Rensburg AJ. Stimulation of normal and abnormal neutrophil motility by propranolol. $S$ Afr med $J, 1978,53,694$.

16 Anderson R, Van Rensburg AJ. The in vitro effects of propranol and atenolol on neutrophil motility and post-phagocytic metabolic activity. Immunology, 1979, 37, 15.

17 Buckley RM, Ventura ES, McGregory RR. Propranolol antagonises the anti-inflammatory effect of alcohol and improves survival of infected intoxicated rabbits. $J$ Clin Invest, 1978, 63, 554.

18 Nakazawa H, Adolphson R, Chaperon R, Hobday J, Townley R, Pauli J. The in vivo and in vitro effects of chronic propranolol administration on the immune response in mice (abstract). J Allergy Clin Immunol, 1976, 57, 200.

19 Benner MH, Enta T, Lockey S, Makino S, Reed CE. The immunosuppressive effect of epinephrine and the adjuvant effect of beta-adrenergic blockade. J Allergy, 1968, 41, 110.

20 Ridley DS and Jopling WH. Classification of leprosy according to immunity. A five group system. Int J Lepr, 1966, 34, 255.

21 Sher R, Anderson R, Rabson AR, Koornhof HJ. Standardization of the nitroblue tetrazolium test and factors affecting its clinical application. $S$ Afr med J, 1974, 58, 209. 
22 Anderson R, Oosthuizen R, Theron A, Van Rensburg AJ. The in vitro evaluation of certain neutrophil and lymphocyte functions following the ingestion of $150 \mathrm{mg}$ oral dose of levamisole. Clin Exp. Immunol, 1979, 35, 478.

23 Weisbart RH, Mickey MR. A microassay for leucocyte migration: analysis of its reproducibility. J Imm Methods, 1977, 16, 269.

${ }^{24}$ Brain P, Marston RH. Rosette formation by human T and B lymphocytes. Europ $J$ Immunol, 1973, 3, 6.

25 Wybran J, Fudenberg HH. Thymus derived rosette forming cells in various human disease states; cancer, lymphoma, bacterial and viral infections and other diseases. J Clin Invest, 1973, 52, 1026.

26 Axelsen NH, Kroll J, Weeke BA. A manual of quantitative electrophoresis - methods and applications. Oslo: Universitets forlaget 1973.

27 Laurell CB. Electro-immunoassay. Scand J Clin Lab Invest, 1972, 29, Suppl 124, 21.

28 Faber WR, Leiker DI, Lonka I, Schellekens PTA. A placebo controlled trial of transfer factor in lepromatous leprosy. Clin Exp Immunol, 1979, 35, 45.

29 McCullough JL, Maren TH. Inhibition of dihydropteroate synthetase from Escherichia coli by sulfones and sulphonamides. Antimicrobial Agents and Chemotherapy, 1973, 3,665 .

30 McDougall AC. Dapsone. Clin Exp Dermatol, 1979, 4, 139. 